\title{
Skeletal changes following surgically assisted rapid maxillary expansion (SARME)
}

\section{Purpose}

Surgically assisted rapid maxillary expansion (SARME) is a common treatment technique in the correction of maxillary transverse deficiency. The purpose of this study was to evaluate nasal and palatal skeletal changes following SARME using Cone Beam Computed Tomography (CBCT) and posterior anterior (PA) cephalograms.

\section{Materials and Methods}

In this retrospective study, the radiographic images obtained from 14 patients with transverse maxillary deficiency before treatment and 6 months after SARME operations were evaluated. The changes in nasal bone width and palatal bone width were measured on CBCT. The changes in basal maxillary width, nasal cavity width and angular measurements were evaluated on PA cephalograms.

\section{Results}

Nasal floor width was measured at the levels of upper first premolar teeth and molar teeth which significantly increased following SARME $(p=0.005$ and 0.017 respectively). Palatal bone width between first premolar teeth and molar teeth also significantly increased ( $p=0.003$ and 0.002 respectively). Basal maxillary width $(p=0.026)$, nasal cavity width $(p=0.024)$ and other angular measurements also significantly increased $(p<0.05)$.

\section{Conclusion}

Nasal and palatal skeletal transverse dimensions increased following SARME. Due to the enlargement of the nasal floor and nasal cavity, it is likely to improve air pass through the nose.

Keywords: Transvers deficiency; maxilla; rapid expansion; skeletal change; CBCT

\section{Introduction}

Maxillary transverse deficiency is a skeletal deformity characterized by unilateral/bilateral cross bite, crowded teeth, and a constricted maxillary arch. Transverse deficiency can either be managed by orthodontic treatment or by combination of orthodontics and surgery depending on patient's age, and bone growth (1). Surgically assisted rapid maxillary expansion (SARME) is a recognized treatment approach in patients with transverse maxillary deficiency. Its primary goal is to achieve skeletal expansion rather than dental expansion and to minimize dental tipping by separating the midpalatal and lateral maxillary sutures. In this technique, the expansion procedure is based on distraction osteogenesis of palatal bones after a surgical operation. SARME also causes craniofacial structural changes such as enlargement of nasal cavity width, nasal volume and palatal vault (2-5). The influence of SARME on the nasal cavity is based on the separation of the nasal lateral walls. The increase in the distance between the nasal cavity lateral walls enlarges the cross-sectional area and increases nasal volume

\author{
Gökhan Gürler', \\ Nevin Kaptan Akar², \\ Çağrı Delilbaşı ${ }^{1}$, \\ İpek Kaçar ${ }^{1} \mathbb{C}$
}

ORCID IDs of the authors: G.G. 0000-0002-6705-3110; N.K.A. 0000-0003-1208-6369; Ç.D. 0000-0003-3347-1151; i.K. 0000-0003-1266-7913.

'Department of Oral and Maxillofacial Surgery, istanbul Medipol University Faculty of Dentistry, Istanbul, Turkey

${ }^{2}$ Department of Orthodontics, Istanbul Medipol University Faculty of Dentistry, İstanbul, Turkey

Corresponding Author: Gökhan Gürler E-mail: ggurler@medipol.edu.tr

Received: 8 May 2017 Revised: 22 June 2017 Accepted: 14 July 2017

DOI: $10.26650 /$ eor.2018.465 
and thus facilitates breathing. The aim of this study was to evaluate the short-term palatal and nasal changes following surgically assisted rapid maxillary expansion. Null hypothesis tested in this study is that the SARME procedure does not affect any of the skeletal measurements.

\section{Materials and methods}

\section{Study sample}

Fourteen patients with transverse maxillary deficiency underwent SARME procedure under general anesthesia at Medipol University School of Dentistry. All the patients were referred from orthodontics department after initial examination and treatment planning. This study was approved by the university local ethical committee (No: 10840098-604.01.01E.21268) and written consents were obtained.

\section{Surgical technique}

The surgical technique was similar to that of Le-Fort 1 osteotomy with an exception of performing down fracture. Surgical technique was performed in all patients by the two oral and maxillofacial surgeons. A mucoperiosteal incision in the maxillary vestibule extended from the right first molar to the left first molar. Maxillary corticotomies were achieved with reciprocating micro-saw. A horizontal cut was done from pyriform aperture to pterygomaxillary fissure, midpalatal and pterygomaxillary sutures were separated and anterior nasal wall was osteotomized. Nasal septum was also separated to prevent deviation during activation period. To prevent irregular fractures, midpalatal suture was separated as well. The tooth borne Hyrax appliance was activated 8 turns $(2 \mathrm{~mm}$ ) at the end of the surgery to verify success of osteotomy and symmetrical separation of the bone segments. The appliance was then deactivated 4 turns and the wound was primarily closed. After one week of latency period the appliance was activated two times a day. Activation was carried on until the planned expansion was achieved. Distractor appliance was left in situ to prevent relapse.

\section{Imaging protocols and measurements}

All patients underwent a CBCT scan using i-CAT Next Generation Cone Beam Computed Tomography (Imaging Sciences International, Hatfield, PA, USA) (16 x $8 \mathrm{~cm}$ FOV, $0.2 \mathrm{~mm}$ slice thickness) being seated and in standard head position. The CBCT scans were taken from all the patients immediately before (T0) and 6 months after the surgery (T1). To assess the skeletal and nasal changes after SARME, the following distances were measured on the coronal CBCT images with the method used by Zandi et al. (6) (Figure 1). NFW4: Nasal floor width at the area of first premolars, $5 \mathrm{~mm}$ above the most inferior part of the nasal floor. NFW6: Nasal floor width at the area of first molars, $5 \mathrm{~mm}$ above the most inferior part of the nasal floor. PBW4: Palatal bone width at the level of a line connecting the palatal root apex of the first premolars. PBW6: Palatal bone width at the level of a line connecting the palatal root apex of the first molars. Postero-anterior (PA) radi- ography was taken from the patients immediately before (T0) and 6 months after surgery (T1).

To assess the nasal changes, the following measurements were performed on PA images with the same methods by Altug-Atac et al. $(7,8)$ and Krykanides et al. (9). Following parameters were measured. (Figure 2). MxR-MxL: Basal maxillary width $M x R / c g / M x L$ : Angle between crista galli and maxillary base points. NC/Lom/VL: Right nasal cavity angle. CN/Lom/VL: Left nasal cavity angle. NC/Lom/CN: Total nasal cavity angle. NC-CN: Nasal cavity width. sn/Lom/VL :Nasal septum angle.

\section{Statistical analysis}

The results were analyzed using IBM Statistical Package for Social Sciences (SPSS) version 22 (SPSS IBM Corp.; Armonk, NY, USA) software. The coherence of parameters to normal distribution was evaluated with Shapiro-Wilks test. Parameters that display normal distribution were evaluated with Paired Samples test, whereas those display asymmetrical distribution were evaluated with Wilcoxon sign test. Confidence interval was set to $95 \%$ and $p$ values less than 0.05 were considered statistically significant.

\section{Results}

Images obtained from 14 patients ( 6 male, 8 female) aged between 18 to 30 years (mean 21.3 years) before SARME (T0) and at 6 months postoperatively (T1) were evaluated. Nasal floor width at the level of upper first premolars and first molars increased following SARME $(p=0.005$ and 0.017 respectively). The increase in palatal bone width at the level of
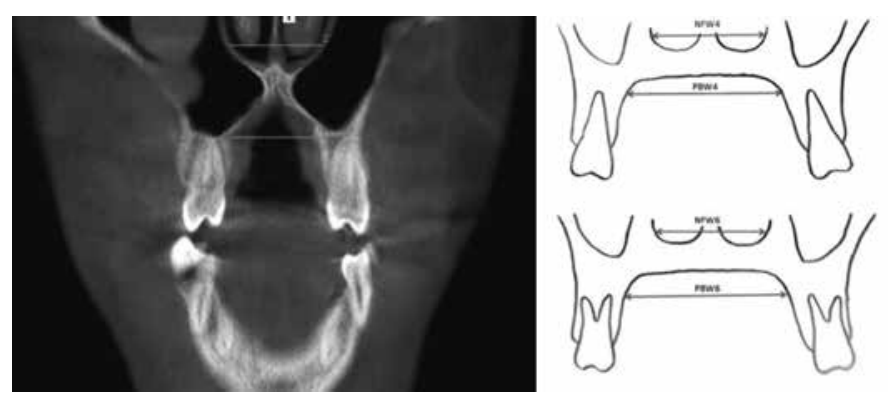

Figure 1. Measurement of nasal and palatal dimensions on cone beam computed tomography (left) and illustration (right).

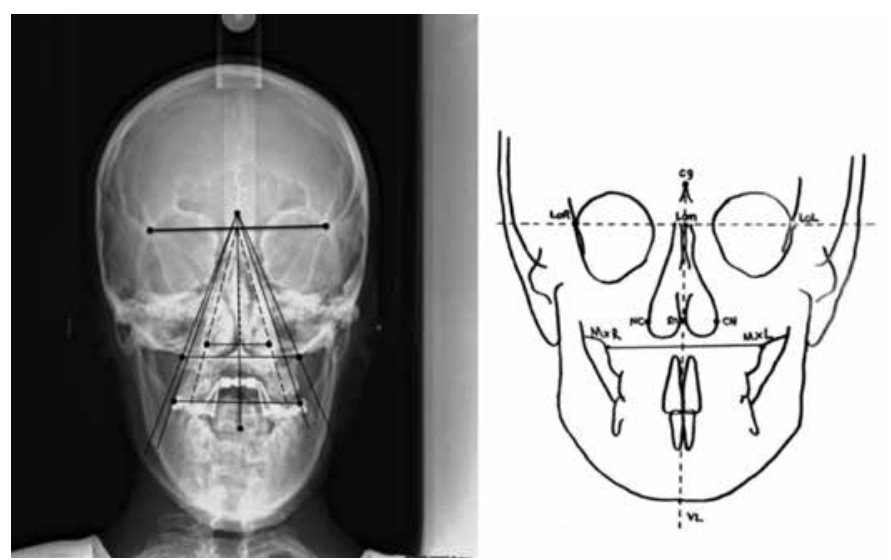

Figure 2. Measurement of orthodontic points on posteroanterior cephalogram (left) and illustration (right). 
Table 1. Findings of cone beam computed tomography measurements

TO

T1

\begin{tabular}{lccc} 
& Mean \pm SD & Mean \pm SD & p \\
NFW4 & $27.42 \pm 3.61$ & $30.63 \pm 4.61$ & $0.001^{*}$ \\
\hline PBW4 & $18.52 \pm 4.37$ & $21.9 \pm 2.79$ & $0.001^{*}$ \\
NFW6 & $29.28 \pm 3.91$ & $31.09 \pm 3.73$ & $0.003^{*}$ \\
\hline PBW6 & $26.97 \pm 4$ & $30 \pm 4.04$ & $0.002^{*}$ \\
\hline
\end{tabular}

*:p<0.05in paired samples $t$ test; SD: standard deviation

Table 2. Findings of posteroanterior cephalometric measurements

$$
\text { T0 T1 }
$$

\begin{tabular}{lccc} 
& Mean \pm SD & Mean \pm SD & p \\
MxR/mxL & $41.70 \pm 3.56(41.5)$ & $44.75 \pm 4.02(43.8)$ & $0.027^{*}$ \\
\hline $\mathrm{MxR} / \mathrm{cg} / \mathrm{mxL}$ & $47.17 \pm 3.27(47.5)$ & $50.58 \pm 3.47(51.5)$ & $0.024^{*}$ \\
$\mathrm{NC} / \mathrm{Lom} / \mathrm{VL}$ & $1.25 \pm 0.69(1)$ & $0.67 \pm 0.52(1)$ & 0.066 \\
\hline $\mathrm{CN} / \mathrm{Lom} / \mathrm{VL}$ & $17.12 \pm 2.31(18)$ & $19.63 \pm 2.65(19.8)$ & $0.027^{*}$ \\
$\mathrm{NC} / \mathrm{Lom} / \mathrm{CN}$ & $33.22 \pm 3.48(33)$ & $37.67 \pm 3.67(39)$ & $0.027^{*}$ \\
$\mathrm{NC}-\mathrm{CN}$ & $20.58 \pm 3.06(21.3)$ & $22.92 \pm 2.93(23.5)$ & $0.026^{*}$ \\
$\mathrm{SN} / \mathrm{Lom} / \mathrm{VL}$ & $16.1 \pm 2.78(15)$ & $18.04 \pm 2.59(16.9)$ & $0.028^{*}$
\end{tabular}

*: $\mathrm{p}<0.05$ in Wilcoxon signed rank test; SD: standard deviation

both first premolars and first molars was found statistically significant ( $p=0.003$ and 0.002 respectively). Basal maxillary width ( $p=0.026)$, angle between crista galli and maxillary base $(p=0.02)$, left nasal cavity angle $(p=0.026)$, right nasal cavity angle ( $p=0.027)$, total nasal cavity angle $(p=0.027)$, nasal cavity width ( $p=0.024$ ) also increased significantly. Nasal septum deviation was evaluated measuring the nasal septum angle at $\mathrm{T} 0$ and $\mathrm{T} 1$ did not yield any significant difference. The findings of the study were presented in Table 1 and Table 2 .

\section{Discussion}

SARME is a well-known technique for the correction of transversal maxillary discrepancies. After SARME, skeletal alterations occur in the maxilla and in the midfacial bones. In the present study we evaluated the outcomes of SARME with posterior-anterior cephalometric radiographs (PA) and cone beam computed tomography (CBCT). Computed tomography is a more precise method for capturing the extent of expansion than the two-dimensional imaging. Three-dimensional visualization of the structures and their movements can be easily inspected with CT images with eliminating the magnification and distortion $(7,10)$. In this study we also used PA cephalograms for angular measurements since the area of Field of View (FOV) in CBCTs was not wide enough to capture crista galli to minimize radiation dose.

The main resistance to distraction movement occurs in the pterygomaxillary, zygomaticomaxillary, and frontomaxillary sutures. These are the buttress areas which are effecting the center of rotation during expansion. Inverted V-shaped horizontal opening movement of the maxillary segments was reported in previous studies $(1,5,11)$ demonstrated a higher amount of expansion in the first premolar than in the molar area following tooth borne SARME. Seeberger et al. (12) reported a $V$ shaped opening of the nasal floor and the palatal arch, but a parallel expansion of the alveolar crest with tooth borne SARME devices. Goldenberg et al. (13) suggested that the greatest expansion occurred in the most inferior and anterior region of the maxilla; however, Zandi et al. (6) reported that transpalatal distractor placed at the molar level provided parallel widening of dental arch, palatal vault and nasal floor. There is also an inverted $\mathrm{V}$ shaped opening that becomes smaller in superior parts as described in other studies with SARPE $(14,15)$. In the present study the alteration of nasal width at the level of first premolars and first molars was statistically significant. SARME provides transversal distraction of lateral nasal walls as well as the maxillary segments.

Posterior anterior cephalometric radiographies were useful in the evaluation in the transversal changes of maxilla and nasal bones. Altug-Atac et al. (7) used PA radiography to evaluate the outcomes of rapid maxillary expansion and orthopedic rapid maxillary expansion. In our study basal maxillary width, angle between crista galli and maxillary base points, right nasal cavity angle, left nasal cavity angle, total nasal cavity angle, nasal cavity width, nasal septum angle were evaluated in PA cephalometric radiographies.

In several studies it was demonstrated that the increase in transversal dimensions of maxilla, enlarges the nasal cavity and decreases the degree of nasal obstruction $(3,16,17)$. However the presence of any nasal deformities or diseases such as polyps or hypertrophic mucosa may prevent air passage through the nasal cavity. Warren et al. (18) found that nasal volume increased $45 \%$ after rapid maxillary expansion and 55\% after SARME. Basciftci et al. (19) reported that both maxillary width and nasal cavity width increased significantly after both RME and SARPE. Enoki et al. (20) presented the results of their study investigating the effect of RME on the dimension of the nasal cavity and on nasal air resistance. They reported an increase in the bony dimension of the nasal cavity and significant improvement of breathing due to decrease in nasal resistance. Seerberger et al. (12) applied tooth borne distraction device after SARME and their results showed that transverse shift of the segments can be achieved over the whole bony plate.

Nasal airflow resistance and nasal volume can alter regarding by horizontal transversal changes of the maxilla. However individual responses vary and it is hard to correlate the nasal changes and subjective improvement. Magnusson et al. (21) reported the alterations in the volume of nasal cavity and the patient's subjective sensation of nasal obstruction. Their results showed nasal volume increased and subjective sensation of nasal obstruction improved. Their findings presented that the improvement in subjective nasal obstruction evaluation was significant in both short and long terms; however, no correlations were reported between subjective parameters and nasal minimum cross sectional area and nasal airway resistance (21). In our study we did not evaluate change in nasal or mouth breathing in our patients; therefore we cannot comment on impact of surgery. 
Intervention to the nasal septum during SARME is variable. The nasal septum is frequently released from palatal base to prevent septal deviation and nasal airway changes. It is believed that unseparated nasal septum is prone to septal deviation during distraction procedure (22); but there are some studies reporting the ineffectiveness of septum osteotomy to septal deviation $(8,12,23)$. Reinbacher et al. (23) investigated the need for releasing the septum during SARME. The deviation of the nasal septum was evaluated by comparing measurements between pre and postoperative CTs. They reported low degrees of septal deviation or side shifting in non-released nasal septa. They declared that there was no compelling reason to release the septum (23). In our study the difference in the nasal septum angles between T0 and T1 radiographies was not statistically significant. We did not encounter septum deviation in our patients due to separation of the septum. SARME is a predictable surgical procedure for the correction of maxillary transverse deficiency. Its effect on nasal airway and breathing should be further evaluated particularly in patients with mouth breathing.

\section{Conclusion}

Nasal and palatal skeletal transverse dimensions increased following SARME. Due to the enlargement of the nasal floor and nasal cavity, it is likely to improve air pass through the nose.

Ethics Committee Approval: Ethics committee approval was received for this study from the ethics committee of İstanbul Medipol University (No: 10840098-604.01.01-E.21268- 13/07/2017).

Informed Consent: This is a retrospective radiographical study. We have ethical approval but we did not need informed consent from the patients.

Peer-review: Externally peer-reviewed.

Author Contributions: GG and ÇD designed the study. NKA and IK generated and gathered the data. GG, NKA and IK analyzed the data. GG and ÇD wrote the majority of the original draft. All authors approved the final version of the paper.

Conflict of Interest: The authors have no conflicts of interest to declare.

Financial Disclosure: The authors declared that this study has received no financial support.

Türkçe öz: Cerrahi destekli hızlı maksiller genişletme (SARME) sonrası iskeletsel değişiklikler. Amaç: Cerrahi destekli hızlı maksiller genişletme (SARME) maksiler transvers yetersizliğin tedavisinde sık kullanılan bir yöntemdir. Bu çalışmanın amacı, SARME uygulanan hastalarda nazal ve palatal iskeletsel değişikliklerin konik ışınlı bilgisayarlı tomografi (KIBT) ve posteroanterior (PA) sefalogramla değerlendirilmesidir. Gereç ve Yöntem: Bu retrospetif çalışmada, maksiler transvers yetmezliği bulunan 14 hastadan SARME öncesi ve girişim sonrası 6. ayda alınan radyografik görüntüler incelendi. Nazal kemik genişliği ve palatal kemik genişliği KIBT üzerinde ölçüldü. Bazal maksiller genişlik, nazal kavite genişlik ölçümleri ve açısal ölçümler PA sefalogramlar üzerinde yapıldı. Bulgular: Üst birinci premolar dişler ve birinci molar dişler seviyesinde ölçülen nazal taban genişliği SARME sonrası anlamlı olarak arttı (sırasıyla $p=0,005$ ve $p=0,017$ ). Palatal kemik genişliği de birinci premolar ve birinci molar dişler seviyesinde anlamlı olarak arttı (sırasılyla $p=0,003$ ve $p=0,002)$. Bazal maksiller genişlik $(p=0,026)$, nazal kavite genişliği $(p=0,024)$ ve diğer açısal ölçümlerin anlamlı derecede arttığı görüldü $(\mathrm{p} \leq 0,05)$. Sonuç: SARME sonrası nazal ve palatal transvers boyutlar artmıştır. Nazal taban ve nazal kavite genişlemesine bağlı olarak burundan hava akışının iyileşmesi beklenebilir. Anahtar kelimeler: Transvers yetmezlik; maksilla; hızlı genişletme; iskeletsel değişiklik; KIBT

\section{References}

1. Kilic E, Kilic B, Kurt G, Sakin C, Alkan A. Effects of surgically assisted rapid palatal expansion with and without pterygomaxillary disjunction on dental and skeletal structures: A retrospective review. Oral Surg Oral Med Oral Pathol Oral Radiol 2013; 115: 167-74. [CrossRef]

2. Babacan H, Sokucu O, Doruk C, Ay S. Rapid maxillary expansion and surgically assisted rapid maxillary expansion effects on nasal volume. Angle Orthod 2006; 76: 66-71.

3. Doruk C, Sokucu O, Sezer H, Canbay El. Evaluation of nasal airway resistance during rapid maxillary expansion using acoustic rhinometry. Eur J Orthod 2004; 26: 397-401. [CrossRef]

4. Garrett BJ, Caruso JM, Rungcharassaeng K, Farrage JR, Kim JS, Taylor GD. Skeletal effects to the maxilla after rapid maxillary expansion assessed with cone-beam computed tomography. Am J Orthod Dentofacial Orthop 2008; 134: 8-9. [CrossRef]

5. Wertz RA. Skeletal and dental changes accompanying rapid midpalatal suture opening. Am J Orthod 1970; 58: 41-66. [CrossRef]

6. Zandi M, Miresmaeili A, Heidari A. Short-term skeletal and dental changes following bone-borne versus tooth-borne surgically assisted rapid maxillary expansion: A randomized clinical trial study. J Craniomaxillofac Surg 2014; 42: 1190-5. [CrossRef]

7. Altug Atac AT, Karasu HA, Aytac D. Surgically assisted rapid maxillary expansion compared with orthopedic rapid maxillary expansion. Angle Orthod 2006; 76: 353-9.

8. Altug-Atac AT, Atac MS, Kurt G, Karasud HA. Changes in nasal structures following orthopaedic and surgically assisted rapid maxillary expansion. Int J Oral Maxillofac Surg 2010; 39: 129-35. [CrossRef]

9. Kyrkanides S, Bellohusen R, Subtelny JD. Skeletal asymmetries of the nasomaxillary complex in noncleft and postsurgical unilateral cleft lip and palate individuals. Cleft Palate Craniofac J 1995; 32: 428-33. [CrossRef]

10. Lagravere MO, Major PW. Proposed reference point for 3-dimensional cephalometric analysis with cone-beam computerized tomography. Am J Orthod Dentofacial Orthop 2005; 128: 65760. [CrossRef]

11. Haas AJ. The treatment of maxillary deficiency by opening the midpalatal suture. Angle Orthod 1965; 35: 200-17.

12. Seeberger R, Kater W, Schulte-Geers M, Thiele OC, Davids R, Hofele $\mathrm{CH}$, Freier K. Surgically assisted rapid maxillary expansion. Effects on the nasal airways and nasal septum. HNO 2010; 58: 806-11. [CrossRef]

13. Goldenberg DC, Goldenberg FC, Alonso N, Gebrin ES, Amaral TS, Scanavini MA, Ferreira MC. Hyrax appliance opening and pattern of skeletal maxillary expansion after surgically assisted rapid palatal expansion: A computed tomography evaluation. Oral Surg Oral Med Oral Pathol Oral Radiol Endod 2008; 106: 812-9. [CrossRef]

14. Bell RA. A review of maxillary expansion in relation to rate of expansion and patient's age. Am J Orthod 1982; 81: 32-7. [CrossRef] 
15. Sandikcioglu M, Hazar S. Skeletal and dental changes after maxillary expansion in the mixed dentition. Am J Orthod Dentofacial Orthop 1997; 111: 321-7. [CrossRef]

16. Doruk C, Sokucu O, Bicakci AA, Yilmaz U, Tas F. Comparison of nasal volume changes during rapid maxillary expansion using acoustic rhinometry and computed tomography. Eur J Orthod 2007; 29: 251-5. [CrossRef]

17. Silverstein K, Quinn PD. Surgically-assisted rapid palatal expansion for management of transverse maxillary deficiency. J Oral Maxillofac Surg 1997; 55: 725-7. [CrossRef]

18. Warren DW, Hershey HG, Turvey TA, Hinton VA, Hairfield WM. The nasal airway following maxillary expansion. Am J Orthod Dentofacial Orthop 1987; 91: 111-6. [CrossRef]

19. Basciftci FA, Mutlu N, Karaman Al, Malkoc S, Kucukkolbasi $H$. Does the timing and method of rapid maxillary expansion have an effect on the changes in nasal dimensions? Angle Orthod 2002; 72: 118-23.
20. Enoki C, Valera FC, Lessa FC, Elias AM, Matsumoto MA, Anselmo-Lima WT. Effect of rapid maxillary expansion on the dimension of the nasal cavity and on nasal air resistance. Int J Pediatr Otorhinolaryngol 2006; 70: 1225-30. [CrossRef]

21. Magnusson A, Bjerklin K, Nilsson P, Jonsson F, Marcusson A. Nasal cavity size, airway resistance, and subjective sensation after surgically assisted rapid maxillary expansion: A prospective longitudinal study. Am J Orthod Dentofacial Orthop 2011; 140: 641-51. [CrossRef]

22. Corega C, Corega M, Baciut M, Vaida L, Wangerin K, Bran S, Baciut G. Bimaxillary distraction osteogenesis--an effective approach for the transverse jaw discrepancies in adults. Chirurgia (Bucur) 2010; 105: 571-75.

23. Reinbacher KE, Wallner J, Pau M, Feichtinger $M$, Karcher $H$, Quehenberger $F$, Zemann W. Surgically assisted rapid maxillary expansion: Feasibility of not releasing the nasal septum. Int J Oral Maxillofac Surg 2013; 42: 321-5. [CrossRef] 